\title{
The effect of formaldehyde treatment before ensiling on the digestion of wilted grass silage by sheep
}

\author{
BY R. C. SIDDONS, R. T. EVANS AND D. E. BEEVER \\ The Grassland Research Institute, Hurley, Maidenhead, Berkshire, SL6 ${ }_{5} L R$
}

(Received 29 January I979-Accepted I June 1979)

\begin{abstract}
I. Wilted perennial ryegrass (Lolium perenne $\mathbf{L}$. cv. Endura) was ensiled without additive or after addition of a mixture of equal volumes of formic acid $(850 \mathrm{~g} / \mathrm{kg})$ and formalin $(380 \mathrm{~g}$ formaldehyde $/ \mathrm{kg})$ applied at a rate of $35 \mathrm{~g}$ formaldehyde/ $\mathrm{kg}$ herbage crude protein (nitrogen $\times 6.25$ ). The digestion of the two silages and the effect of supplemental $\mathrm{N}$ as urea or urea plus soya-bean meal on the digestion of the treated silage was studied using sheep fitted with a rumen cannula and re-entrant cannulas in the proximal duodenum and distal ileum.

2. The additive markedly reduced carbohydrate fermentation and protein degradation in the silo.

3. There were no significant differences between diets in rumen $\mathrm{pH}$, dilution rate, volatile fatty acid production and the molar proportions of acetate, propionate and butyrate. However, rumen ammonia levels and the apparent digestibility of organic matter (OM), gross energy (GE) and cellulose in the stomach were significantly depressed $(P<0.05)$ by the additive. It also reduced $(P<0.05)$ the extent to which the $\mathbf{N}$ of the silage was degraded in the rumen and, with the treated silage, more microbial $\mathbf{N}$ was synthesized in the rumen than food $\mathrm{N}$ degraded, resulting in a net gain of $\mathrm{N}$ between mouth and duodenum, as compared to a net loss with the untreated silage.

4. Supplementation of the treated silage with urea or urea plus soya-bean meal significantly increased $(P<0.05)$ the amount of food $\mathrm{N}$ degraded in the rumen and rumen ammonia levels but had no effect on the apparent digestibility of $\mathrm{OM}, \mathrm{GE}$ and cellulose in the stomach or on the amount of microbial $\mathrm{N}$ reaching the duodenum.

5. The quantity of microbial amino acids entering the small intestine and the apparent digestibility of amino acids in the small intestine were similar for all four diets. However, the quantity of food amino acids reaching the small intestine was significantly higher with the three diets containing the treated silage and consequently the apparent absorption of amino acids from the small intestine was substantially higher with these diets than with the untreated silage.
\end{abstract}

The two major factors limiting animal production from direct-cut silages are low voluntary intake and poor nitrogen utilization (Wilkinson et al. I976). Low intakes have been shown to be correlated with high concentrations of ammonia and volatile fatty acids (VFA) produced by fermentation during ensiling (Wilkins et al. 1971; Demarquilly, 1973; Brown \& Radcliffe, I972) while poor $\mathrm{N}$ utilization is due to extensive degradation of herbage protein to ammonia, both in the silo and in the rumen. The ability of formaldehyde to reduce fermentation during ensiling (Wilkins et al. 1974) and to protect dietary protein from degradation in the rumen (Ferguson et al. 1967) suggests that it should have considerable potential for improving the nutritive value of silages.

Intake studies with formaldehyde-treated silages have given variable results. In some instances intake has been improved (Barry et al. 1973; Barry, 1976) whereas in others intake has been reduced (Wilkins et al. 1974; Tayler \& Wilkins, 1976). Reductions in intake have also been found to be associated with a decrease in cellulose digestion. In experiments with young cattle, Lonsdale et al. (1977) found that the supplementation of a formaldehydetreated silage with urea increased both intake and cellulose digestion. They suggested that formaldehyde treatment may have resulted in an insufficiency of available $\mathrm{N}$ within the rumen to support maximal microbial growth. In this context Beever et al. (1977) found in digestion studies with sheep that although formaldehyde treatment of ryegrass silage 
increased total protein flow at the duodenum, the quantity of microbial protein flowing at the duodenum was substantially reduced.

In order to obtain maximum benefit from the use of formaldehyde as a silage additive, more information is required about its effect on the digestion of silages. The extent of protein protection afforded by formaldehyde treatment is known to be related to the level of formaldehyde applied (Hemsley et al. 1973). In the studies of Lonsdale et al. (1977) and Beever et al. (1977) relatively high levels of 72 and $60 \mathrm{~g}$ formaldehyde $/ \mathrm{kg}$ herbage crude protein $(\mathrm{N} \times 6.25 ; \mathrm{CP})$ respectively were applied. The present experiment was undertaken to examine the effect of a lower level of formaldehyde application $(35 \mathrm{~g} / \mathrm{kg}$ herbage $\mathrm{CP})$ on silage digestion and, in particular, its effect on protein digestion in the rumen. The possibility that the additive may have resulted in an insufficiency of rumen-degradable $\mathrm{N}$ to meet microbial requirements was examined by studying the effect of supplemental urea and urea plus soya-bean meal on the digestion of the treated silage.

The results obtained showed that treatment of wilted grass with a mixture of formic acid and formaldehyde before ensiling considerably increased amino acid supply to the animal without any apparent harmful effect on microbial growth in the rumen. However, they also suggested that 'in practice' it might be preferable to apply less than $35 \mathrm{~g}$ formaldehyde/ $\mathrm{kg}$ herbage $\mathrm{CP}$.

\section{MATERIALS AND METHODS}

\section{Diets}

Primary growth perennial ryegrass (Lolium perenne L. cv. Endura) was cut on 24 May 1976 , using a rotary drum mower, and wilted for $24 \mathrm{~h}$. The wilted material was harvested with a precision chop harvester and ensiled in terylene-reinforced polyvinyl chloride bags either without additive or after addition, at the time of harvesting, of a mixture of equal volumes of formic acid $(850 \mathrm{~g} / \mathrm{kg})$ and formalin $(380 \mathrm{~g}$ formaldehyde $/ \mathrm{kg})$ at a rate of $8.6 \mathrm{l} / \mathrm{tonne}$ fresh material ( $35 \mathrm{~g}$ formaldehyde/ $\mathrm{kg}$ herbage $\mathrm{CP}$ ). After $60 \mathrm{~d}$ the contents of the silos were transferred to polythene bags (approximately $5 \mathrm{~kg}$ fresh weight each), blast frozen at $-23^{\circ}$ for $48 \mathrm{~h}$ and then stored at $-15^{\circ}$ until fed. The four diets studied consisted of the untreated silage (diet $U$ ), the formic acid-formaldehyde-treated silage (diet F) and the treated silage supplemented with either $20 \mathrm{~g}$ urea $/ \mathrm{kg}$ dry matter (DM) (diet FU) or with $10 \mathrm{~g}$ urea and Ioo g soya-bean meal $/ \mathrm{kg}$ DM (diet FS).

\section{Animals}

Suffolk $\times$ Halfbred wethers, 2-3 years old and weighing approximately $50 \mathrm{~kg}$, were used. They were kept individually in metabolism crates in a temperature-controlled animal house with fresh water available at all times. The experiment was begun with four sheep but, after completion of the first period, cannulas in two of the sheep were damaged when the animals were in the resting pens. Consequently these two sheep had to be replaced. A similar problem occurred with one sheep between the third and fourth periods, and only three sheep were used in the fourth period. All sheep were fitted with a rumen cannula and a reentrant cannula in the proximal duodenum and three of the sheep also had a re-entrant cannula in the distal ileum.

\section{Experimental design and analytical methods}

The experiment consisted of four periods and in each period all sheep were given the same diet. Between experimental periods the sheep were housed individually in resting pens for 3 weeks, during which time they were given a diet of dried grass. This design was used rather than a Latin square design, which would have been statistically more sound, because previous experience had shown that, invariably, in digestion studies with surgically modified 
sheep extending over a relatively long time, it is necessary to replace animals during the study. In addition, the design used requires only one donor-sheep for the collection of replacement digesta whereas a Latin square design would require either 4 donor-sheep or long-term storage of digesta.

The diets were studied in the order FU, U, F and FS. Each diet was fed for 6 weeks at the rate of approximately I $\mathrm{kg} \mathrm{DM} /$ sheep per $\mathrm{d}$ given in twenty-four equal hourly portions. Each sheep was given daily at 09.00 and 17.00 hours chromic oxide-impregnated paper via the rumen cannula.

All experimental measurements were made during the last 3 weeks on the diet. Ileal digesta collections were made over one $24 \mathrm{~h}$ period, whilst duodenal digesta was collected subsequently over three consecutive $24 \mathrm{~h}$ periods, using the automatic equipment described by Canaway \& Thomson (1977). Details of the collection procedures used and the preparation of digesta samples have been given by Cammell ( 1977). The flow of digesta constituents was calculated from the content of $\mathrm{Cr}_{2} \mathrm{O}_{3}$ in the digesta which was analysed by an automated colorimetric technique based on the method of Christian \& Coup (I 954). The DM, organic matter (OM), N, cellulose, gross energy (GE) and amino acid contents of food and digesta samples were determined as described by Beever et al. (1977). The quantity of microbial methionine flowing at the duodenum was measured using $\mathrm{Na}_{2}{ }^{35} \mathrm{SO}_{4}$ (Beever et al. 1974). Microbial $\mathrm{N}$ and amino acid flows were calculated from the ratios methionine: $\mathrm{N}$ and methionine : amino acid for rumen microbes. The $\mathrm{pH}$ and concentration of ammonia and VFA in rumen contents were measured in samples taken at two-hourly intervals between I0.00 and I6.00 hours on two consecutive days. Ammonia was measured by an automated alkaline-phenate colorimetric procedure, and the VFA by gas-liquid chromatography (Beever et al. 1976). The daily production of VFA in the rumen was measured using sodium $\left[\mathrm{I}-{ }^{14} \mathrm{C}\right]$-acetate (Weller et al. ${ }^{1967)}$. The dilution rate of rumen water was determined using $\left[\mathrm{I}-{ }^{14} \mathrm{C}\right]$-CrEDTA (Harrison, 1974).

Buffer-soluble $\mathrm{N}$ was measured by incubating I $\mathrm{g}$ finely ground freeze-dried silage in $50 \mathrm{ml}$ buffer (McDougall, I948) at $39^{\circ}$ for I $\mathrm{h}$. The insoluble material was obtained by filtration (Whatman No. 540 filter paper) and assayed for $\mathrm{N}$ by the macro-Kjeldahl procedure. $\mathrm{N}$ insoluble in trichloroacetic acid (TCA) was measured by incubating I $\mathrm{g}$ finely ground freeze-dried material in $40 \mathrm{ml}$ distilled water for $30 \mathrm{~min}$ at room temperature. TCA $(300 \mathrm{~g} / \mathrm{l}$; $8 \mathrm{ml}$ ) was then added and the mixture left at $4^{\circ}$ overnight. Insoluble material was obtained by filtration (Whatman No. 540 filter paper) and its $\mathrm{N}$ content measured.

\section{Statistical analysis}

Diet and time are confounded, but because mature sheep were used it was assumed that time effects would be negligible. The 3-week rest period allowed between diets together with the 3-week dietary adaptation period was assumed sufficient to minimize any possible carry-over effects. Because some animals had to be replaced during the experiment, it was not possible to retain absolute balance between sheep and diets and, therefore, analysis of variance was performed on the results removing only diet effects. Diet means were compared using a Newman Keuls test (Miller, 1966). The standard errors of the means presented in the tables are for full replication.

\section{RESULTS}

\section{Composition of the silages}

The composition of the silages is shown in Table $\mathrm{I}$. The DM, OM, cellulose and GE contents of the two silages were very similar, while the $\mathrm{N}$ and amino acid contents tended to be slightly lower in the treated silage. The effect of the additive in restricting fermentation in 


\section{R. C. Siddons, R. T. Evans and D. E. Beever}

Table I. Composition of the two silages ( $\mathrm{g} / \mathrm{kg}$ dry matter DM) made from wilted perennial ryegrass (Lolium perenne L. cv. Endura)

(DM) (g/kg fresh material)
Organic matter
Gross energy (MJ/kg DM)
Cellulose
Water-soluble carbohydrate
Total nitrogen
Ammonia-N
Amino acid-N
Total amino acids
Trichloroacetic acid-soluble $\mathrm{N}$
Buffer-soluble $\mathrm{N}$
Total organic acids
pH

$\begin{array}{cc}\text { Untreated } & \begin{array}{c}\text { Formic acid-formaldehyde } \\ \text { treated }\end{array} \\ 262 & 264 \\ 905 & 907 \\ 20 \cdot 2 & 20 \cdot 1 \\ 235 & 232 \\ 113 & 219 \\ 32 \cdot 0 & 30 \cdot 7 \\ 4 \cdot 3 & 1 \cdot 1 \\ 21 \cdot 3 & 20 \cdot 3 \\ 166 & 155 \\ 24 \cdot 6 & 11 \cdot 9 \\ 23 \cdot 6 & 12 \cdot 4 \\ 122 \cdot 6 & 47 \cdot 2 \\ 4.2 & 4.6\end{array}$

* A mixture containing equal volumes of formic acid $(850 \mathrm{~g} / \mathrm{kg})$ and formalin $(380 \mathrm{~g}$ formaldehyde $/ \mathrm{kg}$ ) was added to wilted perennial ryegrass (Lolium perenne $\mathrm{L}$. cv. Endura) before ensiling at a rate of $8.61 /$ tonne herbage, i.e. $35 \mathrm{~g}$ formaldehyde/ $\mathrm{kg}$ herbage crude protein.

Table 2. Rumen measurements in sheep given the four perennial ryegrass (Lolium perenne L. cv. Endura) silage diets*

(No. of sheep in parentheses)

Period No....

Diet ...

$\mathrm{pH}$ of rumen fluid

Ammonia concentration $(\mathrm{mg} / \mathrm{l})$

Total VFA produced (mol/d)

VFA molar proportions

Acetate

Propionate

Butyrate

Dilution rate of water $(/ \mathrm{h})$

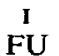

(4)

6.5
308
6.11
0.654
0.257
0.089
0.086

U

(4)
$\mathrm{F}^{3}$

(4)

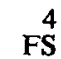

(3)
SEM

$\begin{array}{cccc}6.7 & 6.8 & 6.7 & 0.1 \\ 241 & 107 & 295 & 14 \\ 6.62 & 6.09 & 5.43 & 0.67 \\ & & & \\ 0.670 & 0.675 & 0.638 & 0.016 \\ 0.245 & 0.236 & 0.275 & 0.014 \\ 0.085 & 0.089 & 0.087 & 0.005 \\ 0.078 & 0.078 & 0.080 & 0.012\end{array}$

$\mathrm{U}$, untreated; F, formic acid-formaldehyde treated; FU, treated $+20 \mathrm{~g}$ urea $/ \mathrm{kg} \mathrm{DM}$; FS, treated $+10 \mathrm{~g}$ urea $+100 \mathrm{~g}$ soya-bean meal $/ \mathrm{kg} \mathrm{DM}$.

* For details, see p. 536 and Table $\mathrm{x}$.

the silo was evidenced by a higher water-soluble carbohydrate and lower ammonia $\mathrm{N}$ and organic acid content in the treated silage. The proportion of the total $\mathrm{N}$ soluble in buffer or cold TCA was also much lower in the treated silage, and in both silages the buffer-soluble $\mathrm{N}$ content was similar to the TCA-soluble $\mathrm{N}$ content, indicating that there was very little soluble protein in either silage.

\section{Rumen measurements}

The effect of diet on various rumen measurements is shown in Table 2. There was no significant effect on rumen $\mathrm{pH}$, VFA production, molar proportions of acetate, propionate and butyrate, and on the fractional outflow rate of water. The rumen ammonia concentration was significantly lower $(P<0.05)$ on the treated silage than on the untreated silage, and supplementation of the treated silage with urea or urea plus soya-bean meal increased the concentration to levels which were significantly higher $(P<0.05)$ than those on the untreated silage. 
Table 3. Digestion of cellulose in the stomach of sheep given the four perennial ryegrass (Lolium perenne L. cv. Endura) silage diets*

\begin{tabular}{lccccc}
\multicolumn{5}{c}{ (No. of sheep in parentheses) } \\
Period No. ... & $\mathrm{I}$ & 2 & 3 & 4 & \\
Diet ... & FU & U & F & FS & SEM \\
& $(4)$ & $(4)$ & $(4)$ & $(3)$ & \\
Intake (g/d) & 228 & 237 & 229 & 215 & \\
At proximal duodenum (g/d) & $48^{\mathrm{a}}$ & $36^{\mathrm{b}}$ & $46^{\mathrm{a}}$ & $38^{\mathrm{ab}}$ & $2 \cdot 6$ \\
Digestion in stomach & $180^{\mathrm{b}}$ & $201^{\mathrm{a}}$ & $183^{\mathrm{b}}$ & $177^{\mathrm{b}}$ & $2 \cdot 6$ \\
$\quad$ g/d & $789^{\mathrm{b}}$ & $848^{\mathrm{a}}$ & $801^{\mathrm{b}}$ & $823^{\mathrm{ab}}$ & $1 \mathrm{I}$
\end{tabular}

Means with different superscripts differ significantly $(P<0.05)$.

$\mathrm{U}$, untreated; F, formic acid-formaldehyde treated; FU, treated $+20 \mathrm{~g}$ urea $/ \mathrm{kg}$ DM; FS, treated $+10 \mathrm{~g}$ urea $+\mathrm{I}$ oo g soya-bean meal $/ \mathrm{kg} \mathrm{DM}$.

* For details, see p. 536 and Table I.

Table 4. Digestion of organic matter in the stomach and small intestine (SI) of sheep given the four perennial ryegrass (Lolium perenne $L$. cv. Endura) silage diets*

(No. of sheep in parentheses)

$\begin{array}{lccccc}\text { Period No... } & \text { I } & 2 & 3 & 4 & \\ \text { Diet ... } & \text { FU } & \text { U } & \text { F } & \text { FS } & \text { SEM } \\ & (4) & (4) & (4) & (3) & \\ \text { Intake (g/d) } & 988 & 913 & 898 & 971 & \\ \text { At proximal duodenum (g/d) } & 460^{\mathrm{a}} & 322^{\mathrm{b}} & 446^{\mathrm{a}} & 450^{\mathrm{a}} & 1 \mathrm{I} \cdot \mathrm{I} \\ \text { Apparent digestion in stomach } & & & & & \\ \quad \text { g/d } & 528^{\mathrm{b}} & 591^{\mathrm{a}} & 452^{\mathrm{c}} & 521^{\mathrm{b}} & 1 \mathrm{I} \cdot 0 \\ \text { g/kg intake } & 534^{\mathrm{b}} & 647^{\mathrm{a}} & 504^{\mathrm{b}} & 58^{\mathrm{b}} & 12 \\ & (2) & (3) & (3) & (3) & \\ \text { At distal ileum (g/d) } & 217^{\mathrm{bc}} & 187^{\mathrm{c}} & 279^{\mathrm{a}} & 232^{\mathrm{b}} & 10 \cdot 6 \\ \text { Apparent digestion in SI } & & & & & \\ \quad \text { g/d } & 253^{\mathrm{a}} & 143^{\mathrm{b}} & 166^{\mathrm{b}} & 218^{\mathrm{a}} & 13 \cdot 5 \\ \text { g/kg entering SI } & 538^{\mathrm{a}} & 432^{\mathrm{ab}} & 372^{\mathrm{b}} & 484^{\mathrm{a}} & 25\end{array}$

Means with different superscripts differ significantly $(P<0.05)$.

$\mathrm{U}$, untreated; F, formic acid-formaldehyde treated; FU, treated $+20 \mathrm{~g}$ urea $/ \mathrm{kg} \mathrm{DM} ; \mathrm{FS}$, treated $+10 \mathrm{~g}$ urea $+\mathrm{I} 00 \mathrm{~g}$ soya-bean meal $/ \mathrm{kg}$ DM.

* For details, see p. 536 and Table 1.

\section{Digestion of cellulose}

The digestibility of cellulose in the stomach was high for all four diets (see Table 3). Formaldehyde treatment caused a small but significant reduction $(P<0.05)$ in digestibility, and supplementation of the treated silage with urea or urea plus soya-bean meal had no significant effect.

\section{Digestion of $O M$ and $G E$}

Intake and flow at proximal duodenum and distal ileum of OM and GE are shown in Tables 4 and 5 respectively. The apparent digestibility of OM and GE before the duodenum was significantly lower $(P<0.05)$ with the treated silage than with the untreated silage. Supplementation of the treated silage with urea or urea plus soya-bean meal did not significantly affect the apparent digestibility of $O M$ and GE before the duodenum, but because of a higher $\mathrm{OM}$ intake the amount of $\mathrm{OM}$ apparently digested was significantly increased $(P<0.05)$. In the small intestine, the apparent digestibility of $\mathrm{OM}$ and $\mathrm{GE}$ were 
Table 5. Digestion of gross energy in the stomach and small intestine (SI) of sheep given the four perennial ryegrass (Lolium perenne $L$. cv. Endura) silage diets*

(No. of sheep in parentheses)

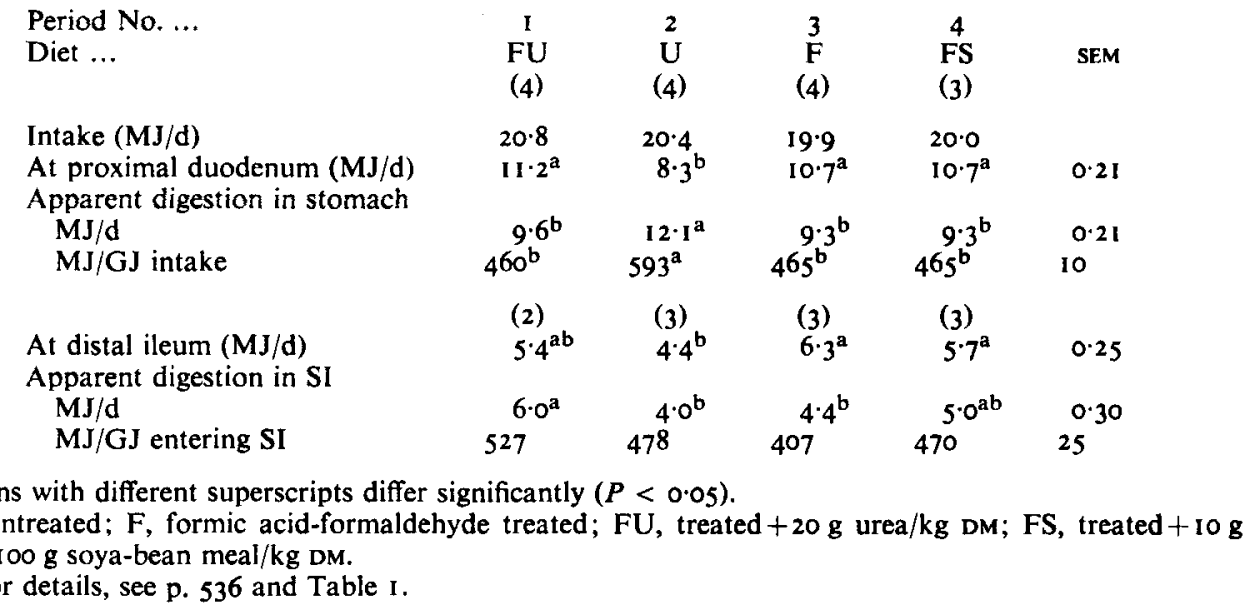

Table 6. Digestion of nitrogen in the stomach and small intestine (SI) of sheep given the four perennial ryegrass (Lolium perenne $L$. cv. Endura) silage diets*

(No. of sheep in parentheses)

\begin{tabular}{|c|c|c|c|c|c|}
\hline $\begin{array}{l}\text { Period No.... } \\
\text { Diet ... }\end{array}$ & $\begin{array}{c}\text { I } \\
\text { FU } \\
(4)\end{array}$ & $\underset{(4)}{\mathbf{U}}$ & $\begin{array}{c}3 \\
\mathbf{F} \\
(4)\end{array}$ & $\begin{array}{c}4 \\
\text { FS } \\
\text { (3) }\end{array}$ & SEM \\
\hline Total $\mathrm{N}$ intake $(\mathrm{g} / \mathrm{d})$ & $42 \cdot 6$ & $32 \cdot 3$ & $30 \cdot 1$ & $40 \cdot 6$ & \\
\hline \multicolumn{6}{|l|}{ Flow at proximal duodenum } \\
\hline Total N (g/d) & $38 \cdot 1^{a}$ & $2 I \cdot 6^{b}$ & $35 \cdot 5^{\mathrm{a}}$ & $37 \cdot 8^{a}$ & $\mathrm{I} \cdot 17$ \\
\hline Ammonia-N (g/d) & $2 \cdot 8^{\mathrm{a}}$ & $1 \cdot 9^{a b}$ & $1 \cdot 5^{b}$ & $2 \cdot 2^{a b}$ & 0.28 \\
\hline Total non-ammonia-N (NAN) $(\mathrm{g} / \mathrm{d})$ & $35 \cdot 3^{a}$ & $19 \cdot 7^{b}$ & $34 \cdot 0^{a}$ & $35^{\cdot} 6^{\mathrm{a}}$ & 0.96 \\
\hline Microbial N (g/d) & $12 \cdot 3$ & $12 \cdot 8$ & I $2 \cdot 3$ & $9 \cdot 3$ & 0.79 \\
\hline Food NAN $\dagger(\mathrm{g} / \mathrm{d})$ & $21 \cdot 5^{b}$ & $5 \cdot 5^{\mathrm{c}}$ & $20 \cdot I^{b}$ & $24^{\cdot 8^{a}}$ & 0.71 \\
\hline \multicolumn{6}{|l|}{ Food $\mathbf{N}$ degraded in stomach } \\
\hline $\mathrm{g} / \mathrm{d} \ddagger$ & $21 \cdot 1^{b}$ & $26 \cdot 9^{a}$ & $10 \cdot 0^{\mathrm{d}}$ & $15.7^{c}$ & 0.80 \\
\hline $\mathrm{g} / \mathrm{kg}$ intake & $496^{b}$ & $83 I^{a}$ & $33 I^{\mathrm{c}}$ & $388^{\mathrm{c}}$ & 24 \\
\hline \multirow[t]{2}{*}{$\begin{array}{l}\text { Microbial } \mathrm{N} \text { at duodenum } / \mathrm{kg} \mathrm{OM} \\
\text { apparently digested in stomach }(\mathrm{g})\end{array}$} & $23 \cdot 3$ & $21 \cdot 6$ & $27 \cdot 3$ & $18 \cdot 0$ & $2 \cdot I$ \\
\hline & (2) & (3) & (3) & (3) & \\
\hline $\begin{array}{l}\text { NAN at distal ileum }(\mathrm{g} / \mathrm{d}) \\
\text { NAN apparently digested in SI }\end{array}$ & $11 \cdot 1^{\mathrm{ab}}$ & $8 \cdot 9^{b}$ & $14 \cdot 7^{2}$ & $12 \cdot 8^{a}$ & 0.86 \\
\hline $\begin{array}{l}\mathrm{g} / \mathrm{d} \\
\mathrm{g} / \mathrm{kg} \text { entering } \mathrm{SI}\end{array}$ & $\begin{array}{l}24 \cdot 8^{\mathrm{a}} \\
691^{\mathrm{a}}\end{array}$ & $\begin{array}{l}11 \cdot I^{c} \\
576^{\mathrm{b}}\end{array}$ & $\begin{array}{l}19 \cdot 6^{b} \\
572^{b}\end{array}$ & $\begin{array}{l}22 \cdot 9^{\mathrm{ab}} \\
642^{\mathrm{ab}}\end{array}$ & $\begin{array}{l}0.85 \\
18\end{array}$ \\
\hline
\end{tabular}

Means with different superscripts differ significantly $(P<0.05)$.

$\mathrm{U}$, untreated; F, formic acid-formaldehyde treated; FU, treated $+20 \mathrm{~g} \mathrm{urea} / \mathrm{kg} \mathrm{DM}$; FS, treated $+10 \mathrm{~g}$ urea + $100 \mathrm{~g}$ soya-bean meal/kg DM; OM, organic matter.

* For details, see p. 536 and Table 1.

+ Assuming $1.5 \mathrm{~g}$ endogenous NAN/d.

† Total $\mathbf{N}$ intake minus food $\mathrm{NAN}$ at duodenum. 
Table 7. Amino acid $(A A)$ digestion in the stomach and small intestine $(S I)$ of sheep given the four perennial ryegrass (Lolium perenne L. cv. Endura) silage diets*

(No. of sheep in parentheses)

\begin{tabular}{|c|c|c|c|c|c|}
\hline $\begin{array}{l}\text { Period No.... } \\
\text { Diet ... }\end{array}$ & $\begin{array}{l}\text { I } \\
\text { FU } \\
(4)\end{array}$ & $\underset{(4)}{2}$ & $\begin{array}{c}3 \\
F \\
(4)\end{array}$ & $\begin{array}{l}4 \\
\text { FS } \\
(3)\end{array}$ & SEM \\
\hline $\begin{array}{l}\text { AA intake }(\mathrm{g} / \mathrm{d}) \\
\text { Flow at proximal duodenum }\end{array}$ & 156 & 167 & 154 & 185 & \\
\hline $\begin{array}{l}\text { Total AA } \\
\text { Microbial AA } \\
\text { Food AA } \dagger \\
\text { Food AA degraded in stomach }\end{array}$ & $\begin{array}{l}172^{\mathrm{a}} \\
64 \\
89^{\mathrm{a}}\end{array}$ & $\begin{array}{l}101^{b} \\
67 \\
23^{b}\end{array}$ & $\begin{array}{l}171^{\mathrm{a}} \\
64 \\
88^{\mathrm{a}}\end{array}$ & $\begin{array}{c}166^{\mathrm{a}} \\
49 \\
99^{\mathrm{a}}\end{array}$ & $\begin{array}{l}5 \cdot 2 \\
4 \cdot 1 \\
4 \cdot 2\end{array}$ \\
\hline $\begin{array}{l}\mathrm{g} / \mathrm{d} \\
\mathrm{g} / \mathrm{kg} \text { intake }\end{array}$ & $\begin{array}{r}67^{c} \\
429^{b}\end{array}$ & $\begin{array}{l}144^{\mathrm{a}} \\
863^{\mathrm{a}}\end{array}$ & $\begin{array}{r}66^{\mathrm{c}} \\
428^{\mathrm{b}}\end{array}$ & $\begin{array}{r}86^{b} \\
465^{b}\end{array}$ & $\begin{array}{r}4 \cdot 2 \\
25 \cdot 1\end{array}$ \\
\hline $\begin{array}{l}\text { Microbial AA at duodenum } / \mathrm{kg} \text { OM } \\
\text { apparently digested in stomach }(\mathrm{g})\end{array}$ & $\begin{array}{r}122 \\
(2)\end{array}$ & $\begin{array}{l}\text { I I } 3 \\
(3)\end{array}$ & $\begin{array}{r}144 \\
(3)\end{array}$ & $\begin{array}{l}94 \\
(3)\end{array}$ & I I 0 \\
\hline $\begin{array}{l}\text { Total AA at distal ileum }(\mathrm{g} / \mathrm{d}) \\
\text { AA apparently digested in SI } \\
\text { g/d } \\
\text { g/kg entering SI }\end{array}$ & $\begin{array}{l}136^{\mathrm{a}} \\
782\end{array}$ & $\begin{array}{l}71^{b} \\
691\end{array}$ & $\begin{array}{l}48 \\
128^{\mathrm{a}} \\
729\end{array}$ & $\begin{array}{l}38 \\
127^{\mathrm{a}} \\
769\end{array}$ & $\begin{array}{r}4 \cdot 9 \\
20 \cdot 4\end{array}$ \\
\hline
\end{tabular}

Means with different superscripts differ significantly $(P<0.05)$.

$\mathrm{U}$, untreated; F, formic acid-formaldehyde treated; FU, treated $+20 \mathrm{~g}$ urea $/ \mathrm{kg} \mathrm{DM}$; FS, treated $+10 \mathrm{~g}$ urea + $100 \mathrm{~g}$ soya-bean meal/kg DM; OM, organic matter.

* For details, see p. 536 and Table I.

$\uparrow$ Assuming endogenous amino acids constitue $110 \mathrm{mg} / \mathrm{g}$ total AA flowing at duodenum.

not significantly different for the untreated and treated silages. Supplementation of the treated silage with urea or urea plus soya-bean meal significantly increased $(P<0.05)$ the apparent digestibility of $\mathrm{OM}$ in the small intestine but had no effect on the apparent digestibility of GE.

\section{Digestion of $N$}

$\mathrm{N}$ digestion in the stomach and small intestine is summarized in Table 6. Intake was similar on the untreated and treated silages but with untreated silage there was a net loss $(10.7 \mathrm{~g} / \mathrm{d})$ of $\mathrm{N}$ between mouth and duodenum, whereas with the treated silage there was a net gain $(5.4 \mathrm{I} \mathrm{g/d})$. Consequently total $\mathrm{N}$ and also non-ammonia-N (NAN) flow at the duodenum were significantly higher $(P<0.05)$ with the treated silage. The quantity of microbial $N$ flowing at the duodenum was similar on the two diets and the increased total $\mathrm{N}$ flow with the treated silage was due to a significant increase $(P<0.05)$ in the amount of food $\mathrm{N}$ reaching the duodenum. Assuming a value of $\mathrm{I} \cdot 5 \mathrm{~g} / \mathrm{d}$ for endogenous NAN flow at the duodenum, the rumen degradability of the $N$ of the untreated silage was 0.83 and only 0.33 for that of the treated silage. Supplementation of the treated silage with urea or urea plus soya-bean meal significantly increased $(P<0.05)$ the amount of food $\mathrm{N}$ degraded in the rumen but had no significant effect on the amount of microbial $N$, total $N$ and NAN flowing at the duodenum. The energetic efficiency of microbial protein synthesis in the rumen expressed as microbial $\mathrm{N}$ flow at the duodenum per $\mathrm{kg} \mathrm{OM}$ apparently digested in the rumen was not significantly different for the four diets.

The apparent digestibility of NAN in the small intestine was very similar with the untreated and treated silage, although the amount apparently digested was significantly higher $(P<0.05)$ with the treated silage. There was a further significant increase $(P<0.05)$ in 
the amount of NAN apparently digested in the small intestine when the treated silage was supplemented with urea.

\section{Digestion of amino acids}

Mean results for the digestion of amino acids in the stomach and small intestine are presented in Table 7. With the untreated and treated silages amino acid digestion followed a similar pattern to $\mathrm{N}$ digestion. Thus amino acid intake was similar with both diets, and the quantity of amino acids of microbial origin flowing at the duodenum was also similar. However, the quantity of food amino acids and total amino acid flow at the duodenum were significantly higher $(P<0.05)$ with the treated silage. Assuming that endogenous amino acid flow at the duodenum constituted $110 \mathrm{mg} / \mathrm{g}$ total amino acid flow it was calculated that only $137 \mathrm{mg} / \mathrm{g}$ amino acids in the untreated silage escaped degradation in the rumen as compared to $572 \mathrm{mg} / \mathrm{g}$ in the treated silage. The apparent digestibility of amino acids in the small intestine was similar with the two diets, but the amount apparently digested was approximately $80 \%$ higher with the treated silage. Urea supplementation of the treated silage did not have any significant effect on amino acid digestion. Supplementation of the treated silage with urea plus soya-bean meal significantly increased $(P<0.05)$ the amount of food amino acids degraded in the rumen but had no significant effect on the quantities of food, microbial and total amino acids flowing at the duodenum or on the amount of amino acids apparently digested in the small intestine. The amount of microbial amino acids flowing at the duodenum per $\mathrm{kg}$ OM apparently digested in the rumen was not significantly different for the four diets.

\section{DISCUSSION}

The studies of Henderson et al. (1972) and Donaldson \& Edwards (1976) showed that pretreatment of wilted grass with formic acid before ensiling restricts fermentation in the silo but does not protect the $\mathrm{N}$ fraction of the herbage from degradation in the silo and in the rumen. Therefore, although in the present study the additive contained formic acid and formaldehyde, it is assumed that its effects on silage digestion were due mainly to the formaldehyde. A mixture of formic acid and formaldehyde was used, because the use of formaldehyde alone can result in a clostridial fermentation in the silo (Wilkinson et al. 1976).

The application of formaldehyde at a rate of $35 \mathrm{~g} / \mathrm{kg}$ herbage $\mathrm{CP}$ to wilted perennial ryegrass before ensiling reduced protein breakdown in the silo and the degradability of amino acids in the rumen. It had no effect on rumen microbial growth and the apparent digestibility of amino acids in the small intestine, and its over-all effect was to increase by approximately $80 \%$ the quantity of amino acids apparently digested in the small intestine. This finding is in general agreement with that of Beever et al. (1977) except that they found that formaldehyde treatment considerably reduced the amount of microbial protein synthesized in the rumen. Microbial growth in the rumen is dependent on an adequate supply of $\mathbf{N}$, and ammonia is the principal source for most rumen bacteria (Bryant \& Robinson, 1962). In vitro studies have suggested that the ammonia concentration required to sustain maximum microbial growth may be as low as $20 \mathrm{mg} / \mathrm{l}$ (Satter \& Slyter, 1974), although in vivo studies have suggested that it may be higher (Okurie et al. 1977; Hume et al. 1970; Miller, 1973). Two factors which affect ammonia availability in the rumen are the degradability of dietary protein and feeding frequency. In the study of Beever et al. (1977), in which twice-daily feeding was employed, the rumen degradability of the silage amino acids was reduced from 0.85 for the untreated silage to 0.23 by the application of $6 \mathrm{~g}$ formaldehyde/ $\mathrm{kg}$ herbage $\mathrm{CP}$. In the present study, amino acid degradability was not reduced to such an extent, being 0.86 for the untreated silage and 0.43 for the treated silage. In addition 
the silages were given continuously, so that the rumen ammonia levels remained relatively constant. Ammonia levels were significantly $(P<0.05)$ lower with the treated silage than with the untreated silage but were adequate to meet microbial requirements, since increases in rumen ammonia levels obtained by urea supplementation of the treated silage were not accompanied by increased microbial growth. In addition to ammonia, a requirement for amino acids for maximum microbial growth has been demonstrated both in vitro (Maeng et al. 1976) and in vivo (Hume, 1970; Maeng \& Baldwin, 1976). However, supplementation of the treated silage with urea plus soya-bean meal, which increased the amount of amino acids degraded in the rumen, did not increase microbial growth.

In recent proposals for calculating the $N$ requirement of ruminants, Roy et al. (1977) suggested that the $\mathrm{N}$ requirement of the rumen microbes should be considered the minimum $\mathrm{N}$ requirement of the ruminant animal. The untreated silage and the treated silage supplemented with urea or urea plus soya-bean meal supplied $26.9,2 \mathrm{I} \cdot \mathrm{I}$ and $\mathrm{I} 5.7 \mathrm{~g}$ rumen degradable $\mathrm{N} / \mathrm{d}$ and in each instance the amount would appear to have been in excess of microbial requirements since with all three diets there was a net loss of $\mathrm{N}$ between mouth and duodenum. In contrast, with the treated silage there was a net gain of $\mathrm{N}$ between mouth and duodenum because more microbial $N(12.34 \mathrm{~g} / \mathrm{d})$ was synthesized in the rumen than food $N(9.95 \mathrm{~g} / \mathrm{d})$ degraded. This could only have occurred as a result of $N$ recycling to the rumen. Recycled N, mainly as urea, can enter the rumen via the saliva and across the rumen wall and, although the relative importance of the two pathways is undecided (Nolan \& Leng, 1972; Engelhardt et al. 1978), significant quantities of $\mathrm{N}$ can be recycled (Weston \& Hogan, 1967). With the treated silage, $2.39 \mathrm{~g}$ more microbial $\mathrm{N}$ was synthesized per $\mathrm{d}$ than food $\mathrm{N}$ degraded although the amount recycled to the rumen was probably greater than this since $\mathrm{N}$ would have been lost as ammonia across the rumen wall (Lewis \& Buttery, 1973).

The quantities of food $\mathrm{N}$ and amino acids that escaped degradation in the rumen were not measured directly but were obtained as the difference between the total and microbial flow at the duodenum less an arbitrary amount of endogenous material. The allowance made for the latter will obviously affect estimates of degradability, and this is aptly demonstrated in the present study. The rumen degradability of $\mathrm{N}$ and amino acids presented in Tables 6 and 7 respectively were calculated using accepted conventions for allowing for endogenous material, i.e. endogenous $\mathrm{N}$ was assumed constant $(\mathrm{I} \cdot 5 \mathrm{~g} / \mathrm{d}$ ) for all diets (Clarke et al. 1966), whereas endogenous amino acids were assumed to comprise I $10 \mathrm{mg} / \mathrm{g}$ total amino acid flow at the duodenum (Beever et al. 1977). On this basis, the calculated rumen degradability of $\mathrm{N}(0.83)$ and amino acids $(0.86)$ were similar for the untreated silage whereas the corresponding values for the treated silage were 0.33 and 0.43 respectively. If no allowance is made for endogenous material the degradabilities would be 0.79 and 0.80 respectively for the untreated silage and 0.28 and $0.3 \mathrm{I}$ respectively for the treated silage. The fact that for both silages $\mathrm{N}$ degradability was similar to amino acid degradability suggests that either the non-protein- $\mathrm{N}$ fraction was not extensively degraded in the rumen, which is contrary to generally accepted opinion, or the endogenous $\mathrm{N}$ contained a high proportion of nonammonia non-amino acid-N. The latter would seem to be unlikely, as Harrop (1974) found that between 650 and $910 \mathrm{mg} / \mathrm{g} \mathrm{N}$ in gastric juice was in the form of protein.

The ability of formaldehyde to increase amino acid supply to the ruminant animal is dependent on its reaction with protein being reversible in the acid conditions of the abomasum and so releasing the protein for subsequent digestion in the small intestine. If too high a level of formaldehyde is applied, irreversible bonding can occur and protein digestibility in the small intestine is reduced (Hemsley et al. 1973). In the study of Beever et al. ( 1977 ), the apparent digestibility of amino acids was reduced by formaldehyde treatment, whereas in the present study it was similar on all diets.

$\mathrm{OM}$ digestion in the rumen was reduced by formaldehyde treatment due mainly to a 
reduction in the amount of amino acids degraded and to a lesser extent to a reduction in cellulose digestion. The extent of digestion of material in the rumen is determined by the rate of digestion and period of time spent in the rumen. Formaldehyde treatment did not affect the fractional outflow rate of water from the rumen, suggesting that the reduction in cellulose digestion was either mediated through a change in the composition of the microbial flora, which decreased the digestive capacity of the rumen, or that in addition to its reaction with protein, formaldehyde also reacts with cellulose and possibly other non-protein organic components of the diet and reduces their susceptibility to microbial attack. In support of the latter, Miller (1972) concluded that formaldehyde protected all components of groundnut meal from rumen degradation.

The results obtained in this study demonstrate that the use of formaldehyde, in conjunction with formic acid, as a silage additive can result in a substantial increase in amino acid supply to the ruminant animal. However, the amount of formaldehyde applied must be carefully controlled in order to ensure that the silage protein is not protected to such an extent that microbial growth in the rumen or protein digestibility in the small intestine, or both, are adversely affected. Neither of these measurements was affected in the present study using $35 \mathrm{~g}$ formaldehyde $/ \mathrm{kg}$ herbage $\mathrm{CP}$, although the rumen-degradable $\mathrm{N}$ of the treated silage was insufficient to meet microbial requirements and microbial growth was dependent on recycled $\mathrm{N}$. The extent of the latter will be determined, at least in part, by the relationship between $\mathrm{N}$ supply to the tissues and tissue requirements and is likely to be lower in productive animals than in mature animals. Therefore, the results suggest that in the practical situation it may be advisable to use a level of formaldehyde application lower than $35 \mathrm{~g} / \mathrm{kg}$ herbage CP.

The authors wish to thank Mrs A. S. Keene, Miss R. L. Nixon, Mr C. L. Wilk and Mr R. J. Barnes for their technical assistance, Mr M. S. Dhanoa for his help with the statistical analysis of the results and $\mathrm{Mr} \mathrm{A}$. R. Austin and his staff for the surgical preparation and after-care of the animals.

\section{REFERENCES}

Barry, T. N. (1976). Proc. Nutr. Soc. 35, 221.

Barry, T. N., Fenessy, P. F. \& Duncan, S. J. (1973). N.Z. Jl agric. Res. 16, 64.

Beever, D. E., Harrison, D. G., Thomson, D. J., Cammell, S. B. \& Osbourn, D. F. (1974). Br. J. Nutr. $32,99$. Beever, D. E., Thomson, D. J. \& Cammell, S. B. (1976). J. agric. Sci., Camb. 86, 443.

Beever, D. E., Thomson, D. J., Cammell, S. B. \& Harrison, D. G. (1977). J. agric. Sci., Camb. 88, 61.

Brown, D. C. \& Radcliffe, J. C. (1972). Aust. J. agric. Res. 23, 25.

Bryant, M. P. \& Robinson, I. M. (1962). J. Bact. 84, 605.

Cammell, S. B. (1977). Tech. Rep. Grassld Res. Inst. Hurley, no. 24.

Canaway, R. J. \& Thomson, D. J. (1977). Tech. Rep. Grassid Res. Inst. Hurley, no. 23.

Christian, K. R. \& Coup, M. R. (1954). N.Z. Jl Sci. Tech. 36A, 328.

Clarke, E. H. W., Ellinger, B. M. \& Phillipson, A. T. (1966). Proc. R. Soc. B r66, 63.

Demarquilly, C. (1973). Annls Zootech. 22, I.

Donaldson, E. \& Edwards, A. (1976). J. Sci. Fd Agric. 27, 536.

Engelhardt, W. V., Hinderer, S. \& Wipper, E. (1978). In Ruminant Digestion and Feed Evaluation, p. 4.I [D. F. Osbourn, D. E. Beever and D. J. Thomson, editors]. Hurley: The Grassland Research Institute.

Ferguson, K. A., Hemsley, J. A. \& Reis, P. J. (1967). Aust. J. Sci. 30, 2 I 5.

Harrison, D. G. (1974). Newsl. Applic. nucl. Meth. Biol. Agric. no. 3, 8.

Harrop, C. J. F. (I974). J. agric. Sci., Camb. 83, 249.

Hemsley, J. A., Reis, P. J. \& Downes, A. M. (1973). Aust. J. biol. Sci. 26, 96I.

Henderson, A. R., McDonald, P. \& Woolford, M. K. (1972). J. Sci. Fd. Agric. 23, 1079.

Hume, I. D. (1970). Aust. J. agric. Res. 21, 305.

Hume, I. D., Moir, R. J. \& Somers, M. (1970). Aust. J. agric. Res. 21, 283.

Lewis, D. \& Buttery, P. J. (1973). In Production Diseases in Farm Animals, p. 201 [J. M. Payne, K. G. Hibbitt and B. F. Sansom, editors]. London: Baillière, Tyndall. 
Lonsdale, C. R., Thomas, C. \& Haines, M. J. (1977). J. Br. Grassld Soc. 32, 171.

McDougall, E. I. (1948). Biochem. J. 43, 99.

Maeng, W. J. \& Baldwin, R. L. (1976). J. Dairy Sci. 59, 648.

Maeng, W. J., Van Nevel, C. J., Baldwin, R. L. \& Morris, J. G. (1976). J. Dairy Sci. 59, 68.

Miller, E. L. (1972). Proc. Nutr. Soc. 31, 27 A.

Miller, E. L. (1973). Proc. Nutr. Soc. 32, 79.

Miller, R. G. (1966). Simultaneous Statistical Inference. New York: McGraw-Hill Book Company.

Nolan, J. V. \& Leng, R. A. (1972). Br. J. Nutr. 27, 177.

Okurie, A. U., Buttery, P. J. \& Lewis, D. (1977). Proc. Nutr. Soc. 36, 38 A.

Roy, J. H. B., Balch, C. C., Miller, E. L., Ørskov, E. R. \& Smith, R. H. (1977). In Proc. 2nd int. Symp. Protein Metabolism and Nutrition, p. I 26. Wageningen: Centre for Agricultural Publishing and Documentation.

Satter, L. D. \& Slyter, L. L. (1974). J. Nutr. 32, 199.

Tayler, J. C. \& Wilkins, R. J. (I976). In Principles of Cattle Production, p. 343 [H. Swan and W. H. Broster, editors]. London: Butterworths.

Weller, R. A., Gray, F. V., Pilgrim, A. F. \& Jones, G. B. (1967). Aust. J. agric. Res. $18,107$.

Weston, R. H. \& Hogan, J. P. (1967). Aust. J. biol. Sci. 20, 967.

Wilkins, R. J., Hutchinson, K. J., Wilson, R. F. \& Harris, C. E. (1971). J. agric. Sci., Camb. 77, 53 I.

Wilkins, R. J., Wilson, R. F. \& Cook, J. E. (1974). Proc. I 2th int. Grassld Congr. Moscow, sect. 3, p. 674.

Wilkins, R. J., Wilson, R. F. \& Woolford, M. K. (1974). Vaxtodling 29, Proc. 5th gen. Mtg Eur. Grassld Fedn, Uppsala, p. 197.

Wilkinson, J. M., Wilson, R. F. \& Barry, T. N. (1976). Outl. Agric. 9, 3. 